\title{
高減衰免震 ゴム
}

\section{深 堀 美 英*}

\section{1.は じめに}

免震用積層ゴムを用いた免震構造ビルの開発に いよいよ拍車がかかってきたよらである、日本で は1985年までに完成した免震ビルが1棟であった のに対し，それから 2 年間で 9 棟が建設され， 1988年には更に8 棟が建設される予定になってい る.これはフランスの小学校(1977), 南フの原子 力発電所 $(1977 \sim 1984)$, ニュージーランドの一般 ビル(1981)及びアメリカの州裁判所(1985)など 1988年までに日本以外の世界各国で建てられた免 震ビルの合計が10棟足らずであることを考えれ ば，日本における最近の免震構造の普及がいかに 急速であるかを物語っている。

一方このよらな免震ビルの開発が最初は大手ゼ ネコンと呼ばれる一部の大手建設会社を中心に進 められたのに対し，最近はその他のゼネュン各社 の参入が目立ち今年中には約30の建設会社が免震 ビルの大臣認定を得るための建設センター評定を 終了，又は受けることになっている.

また兔震構造を適用する建物の種類にも最近変 化が見られる、すなわら最初に建てられたほとん どの免震ビルがゼネコン各社の自社用研究棟や寮 などであったのが，昨年頃から一般的なマンショ ソやオフィスビル, ハイテクビルなどへと適用範 曲が払大している。

更に今一つ，兔震ビルの普及を急速なるのにし ている要因として免震ビルの有效性がいくつかの 地震で立証されてきたことがあげられる，例えば 1987年12月17日の千葉県沖20 km(マグニチニー ド6.7)の地震は, 千葉が震度 5 (強震), 東京など が震度 4 (中震) とい5, 関東地方としてはかなり 大きな地震であった。この結果千葉では窟ガラス が割れたり，ケガ人が出るなどの被害があった。 この地震に対する免震ビルの効果が数多く報告さ れているが，その中でる例えば千葉県に近い西船 橋にある竹中工務店の独身寮と, 清瀬にある大林
組の R \& D センターに関する観測結果が図 11), 図 $2^{2)}$ に示されている。これらのデータは，免震 構造にすることによって建物に加わるエネルギー (加速度)が地震のエネルギーの1/4程度に減少さ

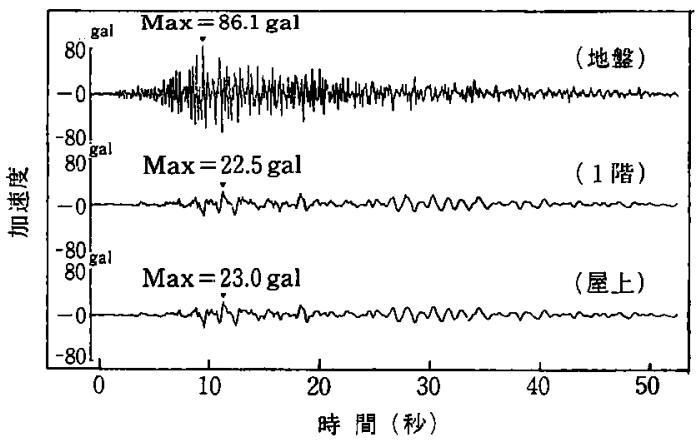

図 1 地震観測結果 : 竹中工務店独身寮 (兔票ビル)

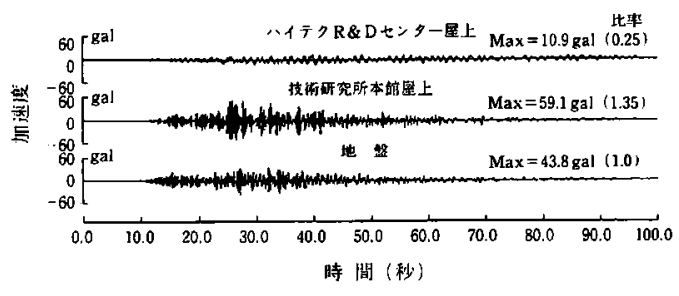

図 2 地震観測結果：大林組 R/Dセンター(免震 ビル) と技術研究所 (非免震ビル)

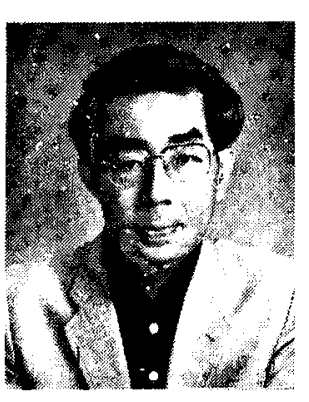

*株)ブリヂストン(テ187 東 京都小平市小川東町3-11) 研究開発本部, 主任研 究員、昭和45年九州大学工 学部応用化学科修士課程卒 業. 同年ブリデストンタイ ヤ(侏)(当時)入社. $49 \sim 51$ 年 ロント゚ン大学クィーンメリ 一カレッ溜学. Ph.D.

〈趣味〉テニス, 野球, 絵 画. 
れることを立証している。

以上述べたようにいまや免震ビルは，最初の “ものめずらしさ”の段階から“実質的効果を求 めて”の段階に入ったと考えてよい，そしてその よらな背景の下で今求められているものは兔震構 造を真に普及させるための優れた免震用デバイス の開発であり、特に免震ゴムとダンパーの開発は そのポイントになっている.

\section{2. 高隇衰免震ゴムとは}

免震構造は基本的には 2 つの要素から成り立っ ている、1つは，ば权支承であり，む5 1 つはタ ンパーである.ばね支承というのは，平常的に建 物を直接支えるとともに地震時には建物の水平方 向の摇れの周期を地震波の周期より長周期側へず らす動きをするものであり，建物を支えた状態で その水平方向のゆっくりした往復運動を保証する ばねの役割を果たす。このばね支承として最むよ く用いられているのがゴムと鉄板の積層体である 免震用積層ゴム (免震ゴム)である3)(図 3).

一方ダンパーは建物の地震時の水平変位を一定 值以内に打さえるとともに，地震時の建物の摇れ をできるだけ早く減衰させる働きをする。このよ らなダンパーには金属(鋼棒, 鉛棒)の塑性変形を

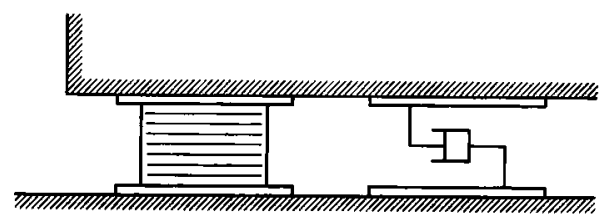

（免震ゴム）（タンパー）

因 3 免震構造の基本構成

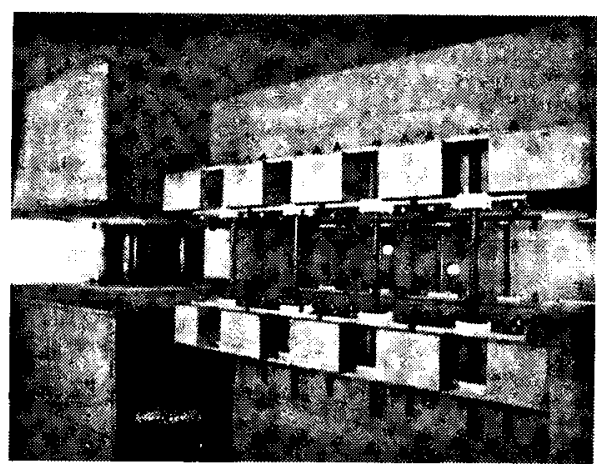

図4免震ゴムと鋼棒ダンパで出来た免震構造
利用する弾塑性ダンパー，粘性体のせん断抵抗力 を利用する粘性ダンパー更にオリフィスを用いる オイルダンパーなどがあり，ゼネコン各社が独自 のダンパーを開発している.

日本では免震ゴムとダンパーを並列に設置する 免震構造が一般的である。例えば大林組の R \& Dセンターは免震ゴム14個と鋼棒ダンパー96本 で構成された免震ビルである2（図4)，その他， 鹿島建設も兔震ゴム之鋼棒ダンパー，竹中工務店 は免震ゴムと粘性ダンパー，清水建設は免震ゴム とオイルダンパーをおのおの並列に設置して使用 している. しかしながら免震ゴムと独立のダンハ 一を並列に設置すると，ダンパー自体の費用に加 えダンパー施工費用及びメインテナンス費用がか さむため全体としてかなりコスト高になることが さけられなかった．更に免震ゴムとダンパーが休 下に林立するため床下の空間が狭くなり作業上も 見ばえ的にも好ましくないすのとなっていた。

これに対し，免震ゴムに直接減衰 (ダンピング) 効果を付与した，ばね効果と減衰効果兼備の一体 型兔震ゴムが開発されている. その1つが鉛入り 免震ゴムであり，免震ゴムの中心部をくり抜きそ の部分に鉛を封入したものである(図 5)，特性的 には免震ゴムと鉛棒ダンパーを並列に設置したも のと同じである。一方, ばね効果, 減衰効果兼備 の一体型の別のタイプとして本報告で述べる高減 衰免震ゴムがある，これはダンパーを併用するの でなく、ゴム自体に高減衰性，高ヒステリシス性 を与えることによりばね効果とダンピング効果を 備えたものとなっている。このよらな高減衰免震 コムの一例としてはカルフォルニアの州裁判所に 用いられたものがあるが，減衰能力の大きさなど

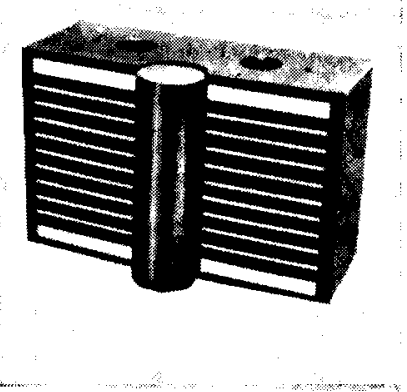

図 5 鉛入りー体型免震ゴム 
に問題があり今までのところ日本では使用されて いない(図18参照).

ところで免震構造体においてどの程度の減衰能 力を必要とするかは建物の設計者の思想にるよる が，日本に拈けるぜネュン各社の求める值は多く の場合，等価粘性減衰定数が0.15以上となってい る(後述).このよ5に高減衰免震ゴムに求められ る性能はまずゴム自体の減哀能力が極めて高いこ とである。一方ばね支承としての働をを考劣ると ばね定数(剛性)の温度依存性や振動数依存性が小 さいこと，クリープの小さいことが必要であ る3).一般的には材料に批ける高ヒステリシス性 と低温度依存性，低クリープ性は相反するるので ありそれらの両立化が開発のポイントになる。 更に長期耐久性が必要なのも当然である。

以上のように高減衰免震ゴムの開発にはいくつ かの困難な課題を解決しなければならないが，今 回ブリヂストンで開発された高減衰兔震ゴム (MRB-HD)はこれらの課題にチャレンジした製 品である。したがって本報で説明する高減衰免震 ゴムとは特に注釈がない限りこの MRB-HDを 指するのとする。

\section{3. 高減衰免震ゴムのばね特性と減哀特性}

高減哀免震ゴムの構造を図 6 亿示寸。長期 $(60$ 年)耐久性を確保するために高减衰ゴムを外皮ゴ ムで保護する構造となっている。

さて高减衰免震ゴムのばね特性と减衰特性は次 のようにして求められる.兔震コムに一定の鉛直 荷重を与えた状態で，水平方向に一定振幅 $(0.5$ $\mathrm{Hz}$ の $\mathrm{Sin}$ 波)で 5 回動的変形を与之る(図 7). 次 に振幅を少し大きくして同様の変形を与える。こ のように㮌次振幅を大きくして測定 (1st+イクル (図8))した後, 再び低振幅から高振幅まで繰り 返し2ndサイクルとする。このとさ得られるヒ ステリシスループ(図 9)から，等価せん断剛性 $\left(K_{H}\right)$ と减衰性能の指標となる等価粘性減言定数

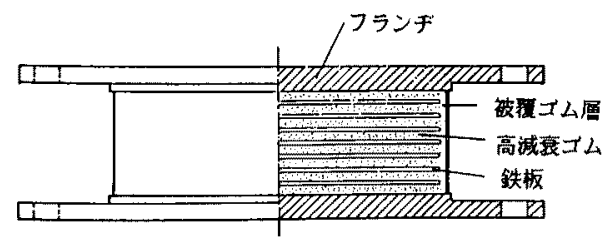

図 6 高减衰免震ゴム

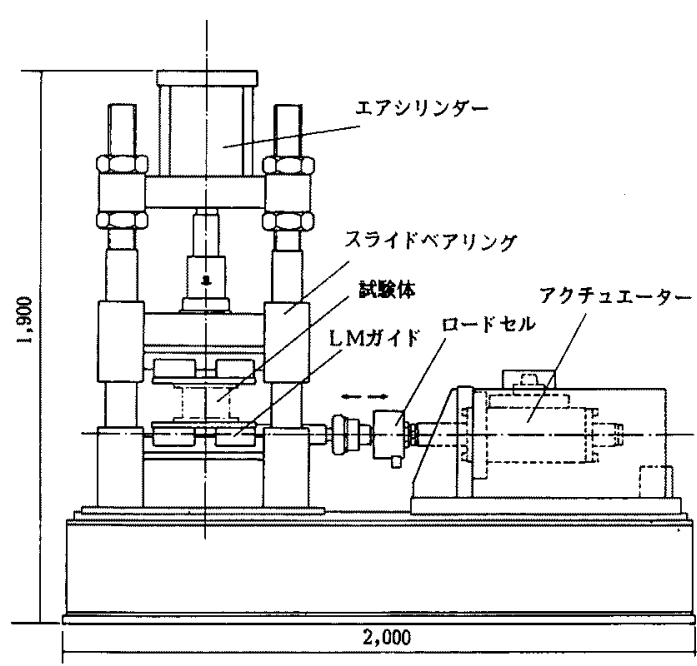

目 7 動的王縮，せん断試験機

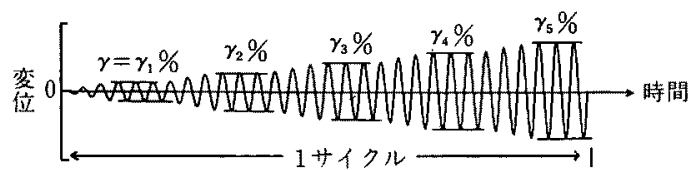

図 8 加振方法

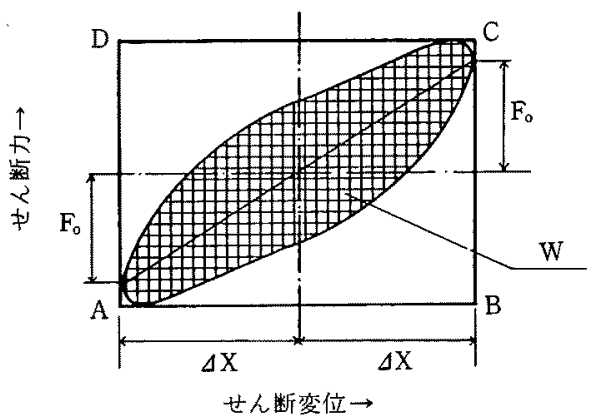

図 9 動的特性值の定義

$\left(h_{\text {eq }}\right)$ が式(1)と式(2)で与えられる.

$$
\begin{aligned}
& K_{H}=F_{0} / \Delta X \\
& h_{\mathrm{eq}}=\frac{1}{\pi} \cdot \frac{W}{\Delta A B C}
\end{aligned}
$$

そこで高隇衰免震ゴムについて得られた測定結果 を以下に示す。

\section{1 変形量依存性}

最初に減衰能力の小さいゴムの代表例として標 準的天然ゴム采免震ゴムのヒステリシスループを 困10に示す，ヒステリシスループのふくらみは非 


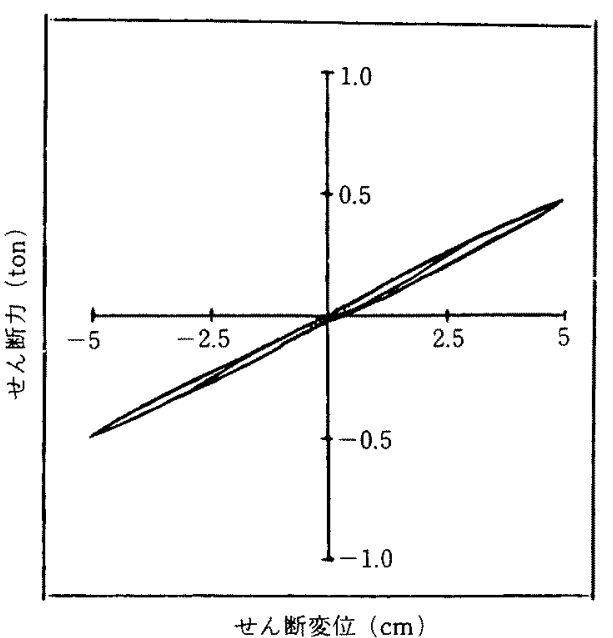

因10 標準免震コムのヒステリシスループ

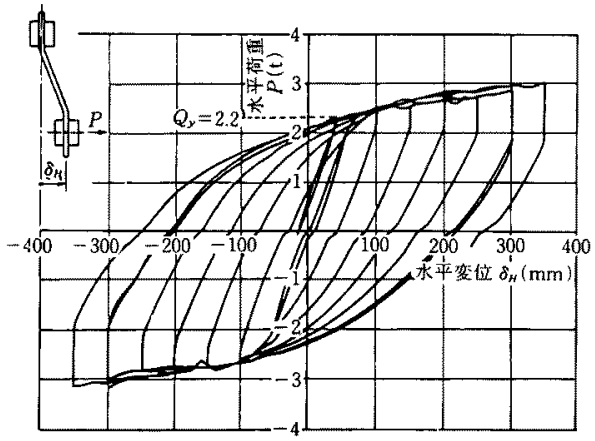

図11 鋼棒ダンパーのヒステリシスループ2)

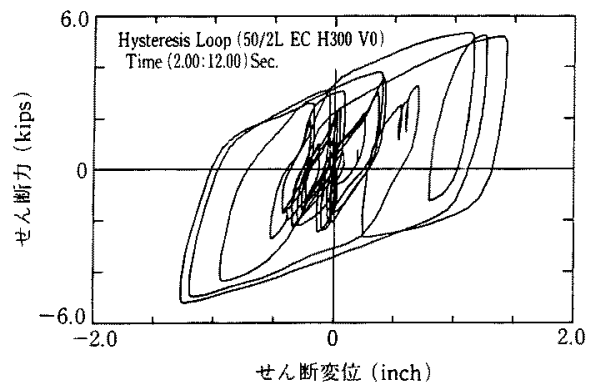

図12鉛入り一体型免祳ゴムのとステリシスルー プ4)

常に小さく $h_{\mathrm{eq}}=0.025$ となっている.一方鋼棒ダ ンパーのとステリシスループを図11に，鉛入り一 体型免震ゴムのヒステリシスループを図12に示 す。これらのループの特性として大きな減衰能力 が得られる代りに変位の小さい領域ではかなり高

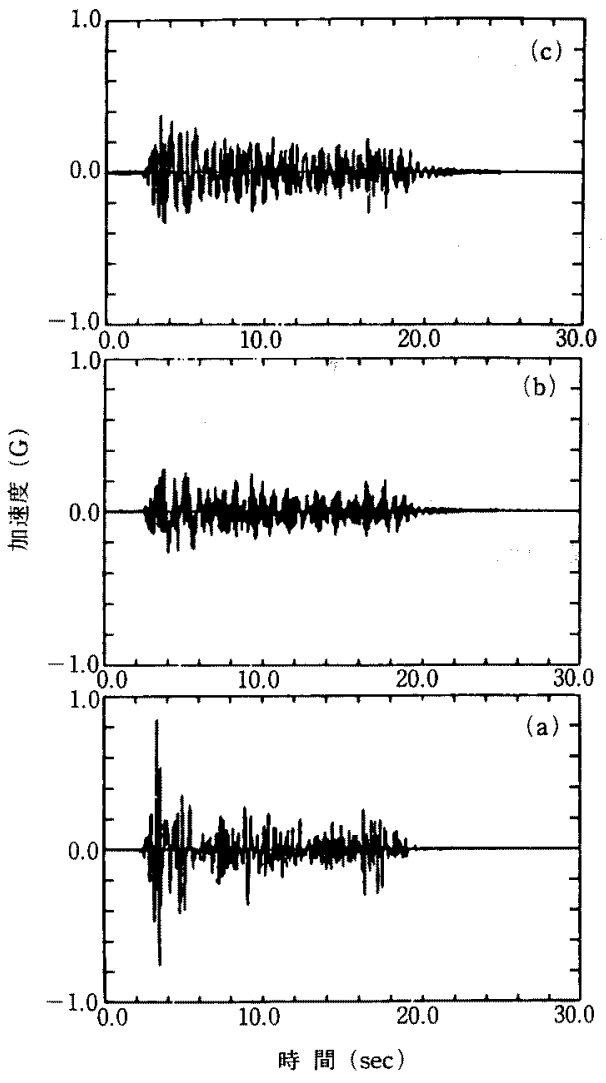

図13鉛入り一体型免震ゴム用いた免震鉄骨体を El Centro 波で加振したときの店答加速度 (G) 時間変化 : (a)加振台, (b) 1 階，(c) 5 階

い剛性を示すここのため小さい地震には免震効果 を発揮しにくいのではないかと考えられて扰り， ゼネコン各社が独自の工夫をこらしている，更に 今一つの特敹として，弾塑性ダンパーの場合図 11，図12が示すように基本的にヒステリシスルー プが菱型となっており加荷時に比べ除荷時の剛性 がかなり高くなるため，高周波振動領域で共振現 象を起こす可能性がある．図13，図14はかなり大 きな鉛を免震ゴムの中心部に封入した一体型兔震 ゴムを用いて行われたカルフォルニア大学での実 験結果である4)。これは加振機の上に組立てられ た鉄骨構造体(コンクリートブロックを載せて重 量調整)の基礎底部にこの一体型免震ゴムを敷き， 地震波(El Centro 波)で加振した時の鉄骨体の応 答加速度を測定したものである．図13の(a)は加振 台，(b)，(c)はおの括の鉄骨体の 1 階及び 5 階にお。 ける加速度の時間変化を $\mathrm{G}$ 単位で示したもので 


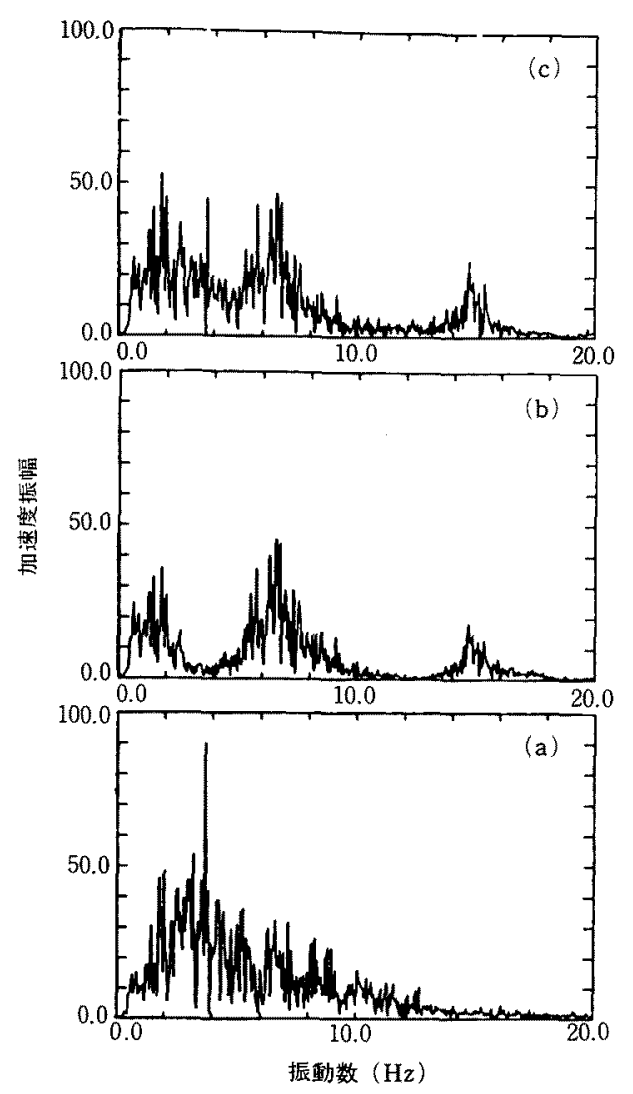

図14図13で与えられた各加速度の振動数特性：(a) 加振台, (b) 1 階, (c) 5 階

あり，一方図14の(a)，(b)，(c)は図13に与えられた 各加速度の振動数特性(フーリエスペクトル)であ る.図13よりこのような免震構造とすることに より最大加速度が加振台上の $0.85 \mathrm{G} か ら 1$ 階で $0.28 \mathrm{G}, 5$ 階で0.38 G に減少していることがわか る。一方，図14を見ると，1階，5階では加振機 には含まれないかなり強い振動が $15 \mathrm{~Hz}$ 付近に現 われている。これは前述の除荷時の高剛性に起因 する共振現象と考えられ，免震構造の設計時に考 虑すべき項目の一つであろら．

さて高減衰免震ゴムのヒステリシスループにつ いて，ひずみのやや小さい領域での結果を図15 (a)，(b)に，ひずみの大きい領域までの結果を図16 (a)，(b)に示す，高減衰免震ゴムの特徵としてほぼ きれいな笹の葉状のヒステリシスループを描くこ とがわかる．したがって弾塑性ダンバーと異なっ て加荷時之除荷時の剛珄の差が小さく，ループの 頂点間を結ぶ直線で系の剛性が近似できる，高減

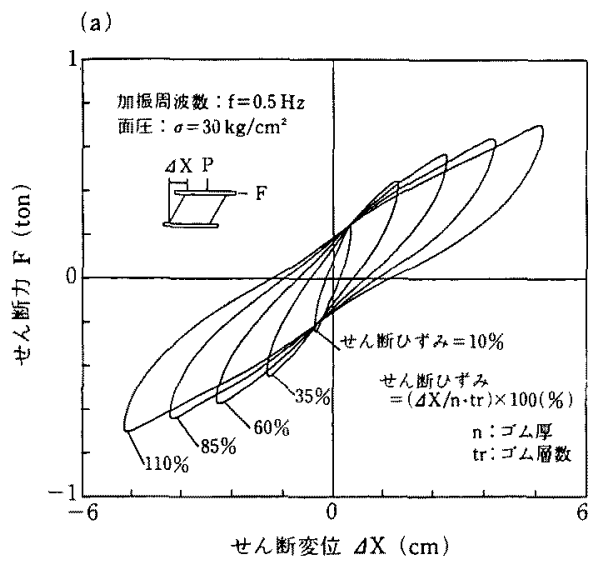

(b)

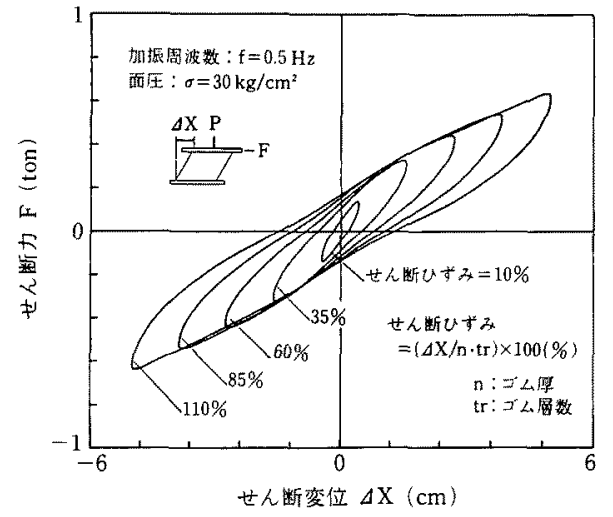

図15高減衰免震ゴムの中变形領域でのヒステリシ スループ: (a) 1stサイタル，(b) 2ndサイクル

衰免震ゴムの場合，1st サイクルに対し2nd サイ クルのほらが成性が低下しループ全体が丸味をお びる傾向がある，そこで，得られた水平方向の剛 性をせん断ひずみに対してプロットしたのが図17 である. 高減哀ゴムは典型的な力学的非線形性を 示す材料であり，ひずみの小さい領域ではひずみ の減少に伴って剛性が急激偪加することがわか る、ただしひずみが50\%以上になるとこの傾向は ゆるやかになり，100\%を越えると300\%程度まで は㤝とんど变化しない，図18(a)は高减衰免震ゴム を一方向にのみ変形させたときの S-S 曲線であ るが，せん断ひずみが350\%を超えると剛性が再 び增加し，550\%で破断している様子がわかる。 図18(b)はその之きの破断面写真である。フランジ 近傍の接着部で破壊しているが，完全なゴム破壊 であることを示している。 
(a)

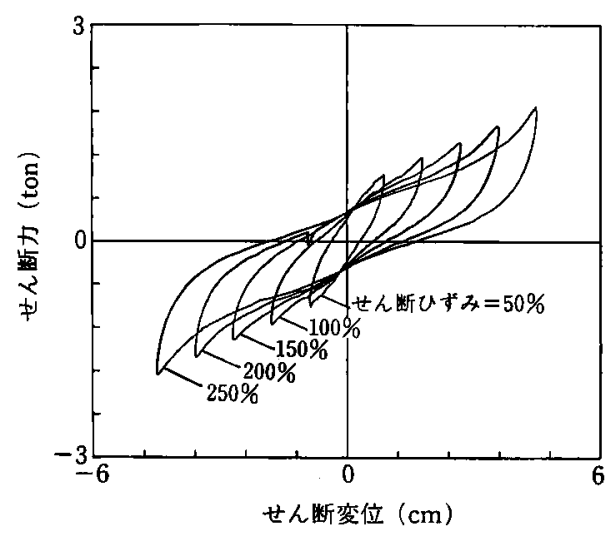

(b)

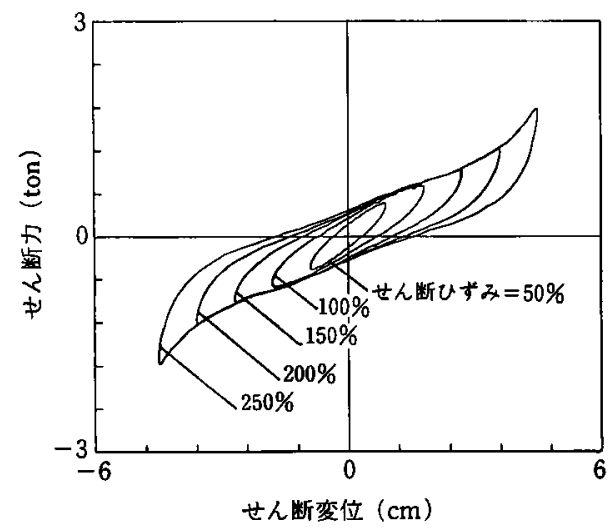

図16高減衰免震ゴムの大変形領域までのヒステリ シスルーブ : (a) 1st サイクル, (b) 2nd サイク ル

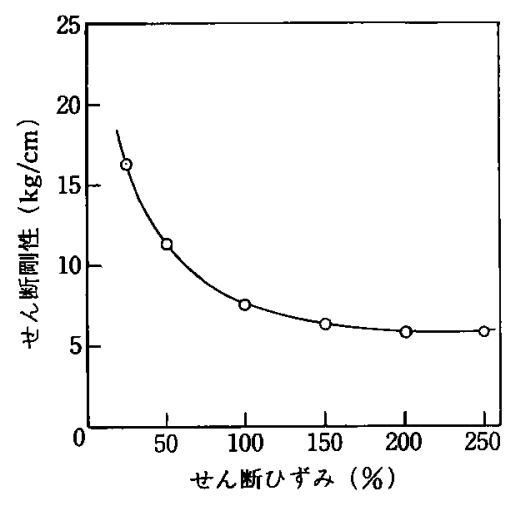

困17 高減哀免震ゴムの力学非線形曲線

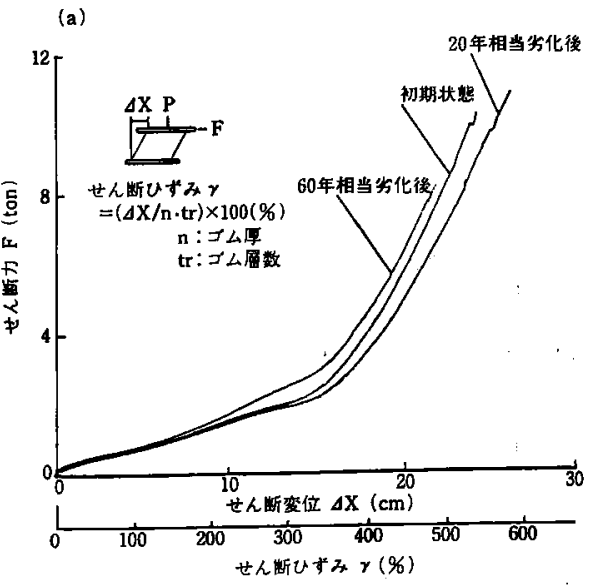

図18(a) 高减衰免震ゴムの静的 S-S 曲線

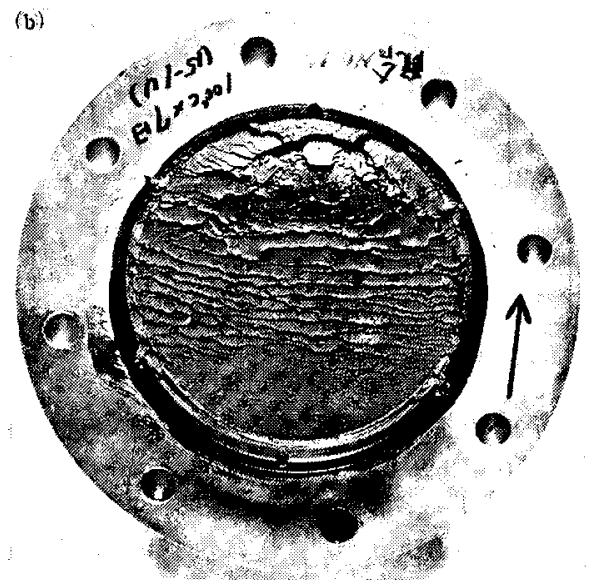

因18(b) 高减哀免震ゴムの破断面, 矢印は破㘊の進 行方向を示す

一方等価粘性减衰定数 $\left(h_{\mathrm{eq}}\right)$ のひずみ借存性を 図19に示す，ひずみが大きくなるにつれ $h_{\mathrm{eq}}$ は若 干低下する傾向があるが，設計値として定められ た許容せん断ひずみ值200\%までは $h_{\text {eq }}$ が0.15を超 えており，特にひずみが $100 \%$ 以下では $h_{\mathrm{eq}}$ が 0.2 に近い值となっている、これらの結果は高減哀免 震ゴム (MRB-HD) が免震構造に必要な減衰能力 を充分備杂ていることを示している。 ちなみに力 ルフォルニアの州裁判所で用いられた高減衰免震 ゴムの $h_{\mathrm{eq}}$ を図19に併記しているが，MRB-HD に比べ $h_{\mathrm{eq}}$ の值が約1/2 となっている.

\section{2 鉛直荷重依存性}

一般に免震ゴムの水平方向の剛性は鉛直荷重俵 存性を示し，一定の鉛直荷重を加えた状態で水平 


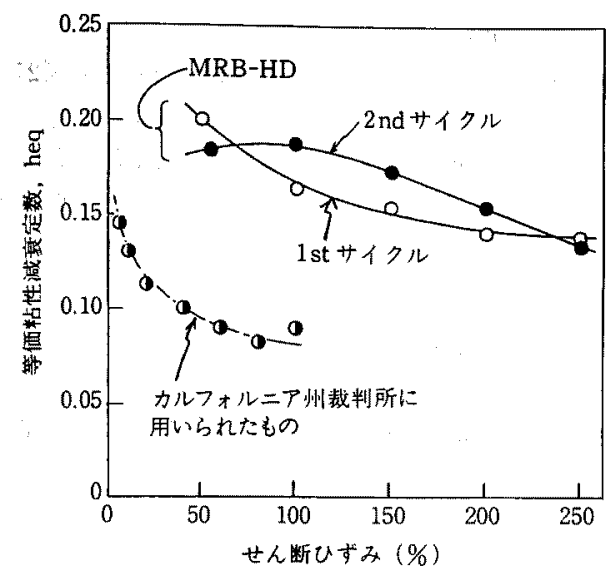

図19 高減衰兔震ゴムの等価粘珄減衰定数 (MRBHDとカルフォルニア州栽判所に用いられ たものとの比较).
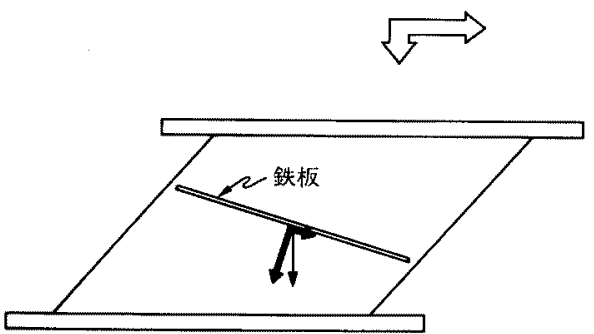

図20せん断変形を加えたとき，免震ゴム内で起こ るインサート鉄板の回転による东平分力の発 生

方向に変形させたときの水平方向の剛性は鉛直荷 重の増加に伴って低下する，これは図20に示すよ らに積層ゴムがせん断変形するときインサート鉄 板が回転し更に鉄板の一部に曲げが起こるた

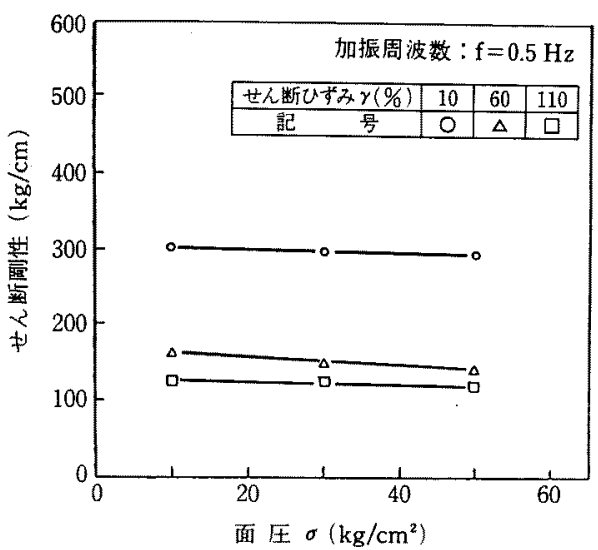

図21 せん断剛性の面圧依存性

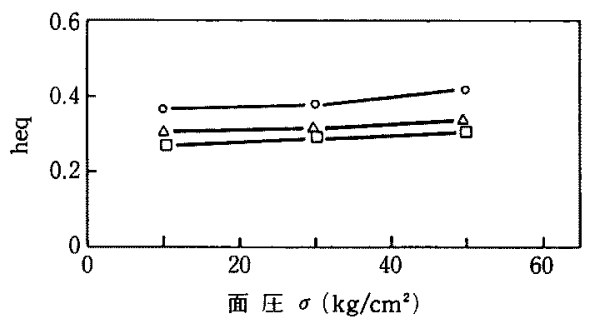

図22 等価粘性減衰定数の面圧依存性(記号は図21 と同じ)

め5), これに鉛直方向の力が加わるとせん断方向 の分力が発生しせん断変形がより容易に起こりや すくなる，すなわちせん断剛性が低下する現象で ある。

高減衰兔震ゴムの場合も同様の傾向を示し，鉛 直荷重が増加するにつれ水平方向の用性が若干低 下する(図21)。一方， $h_{\mathrm{eq}}$ は鉛直荷重が増加する

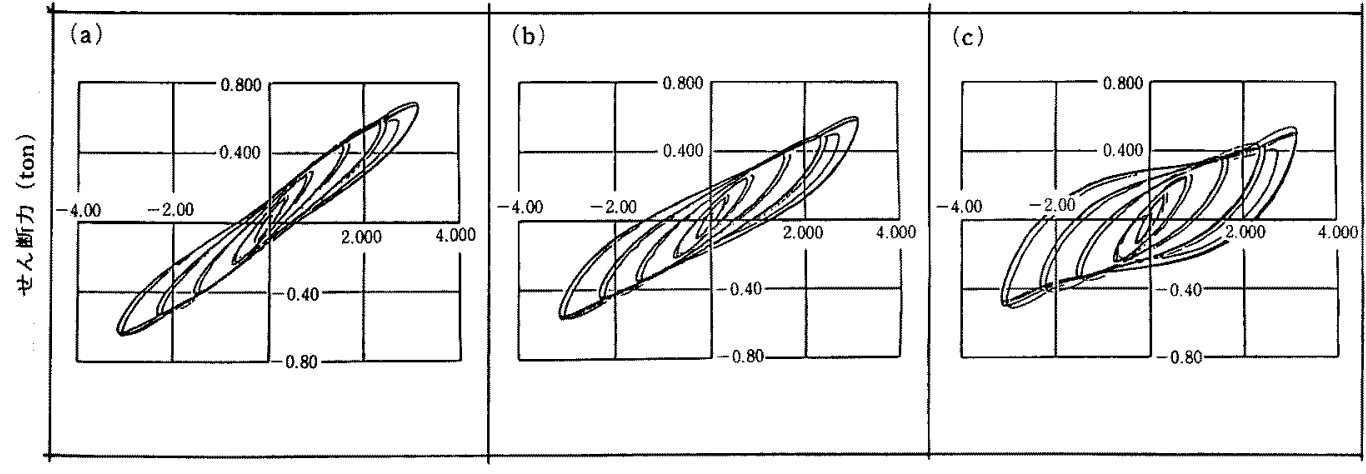

せん断変形 $(\mathrm{cm})$

図23 ゴム厚の大きい高减衰免震ゴムに拈けるヒステリシスループの面圧依存性：鉛直荷重が，(a) 0 ton, (b) 4 ton, (c) 8 ton. 
につれ若干増加する傾向がある(図22).

これらの極端な例として、ゴム層がかなり厚い 形状の高減衰免震ゴムに打けるヒステリシスルー プの鉛直荷重依存性を図22に示すが，鉛直荷重の 増加に伴ってヒステリシスループの形状が変化し $h_{\text {eq }}$ が著しく增大寸る(図23)ことがわかる゙）

\section{3 繰り返し变形依存性}

前に述べたように，高减衰免震ゴムでは1 stサ イクルと2ndサイクルの用性の差がかなり大き い(図15，図16)。ただ図24に見られるように一 定変形量で連続繰り返し变形させたとさの岡性は, 3 回以後になるとほぼ一定值になる。一方, 等価 粘性減衰定数 $h_{\mathrm{eq}}$ は繰り返し変形を与えてもにと んど変化しない(図25)。

高減衰免震ゴムが繰り返し変形を受けたとさ兔 震ゴムの内部，外表面部で外気温度に対してどの 程度の温度上昇が起こるかを図26に示す，当然の ことながら温度上昇の程度は変形量や振動数によ って異なるが，免震ゴムが地震時に最大ひずみる 受ける回数は10〜20回程度と考えれば温度上昇に 伴ら性能の変化は皃とんど無視してもさしつかえ ない.

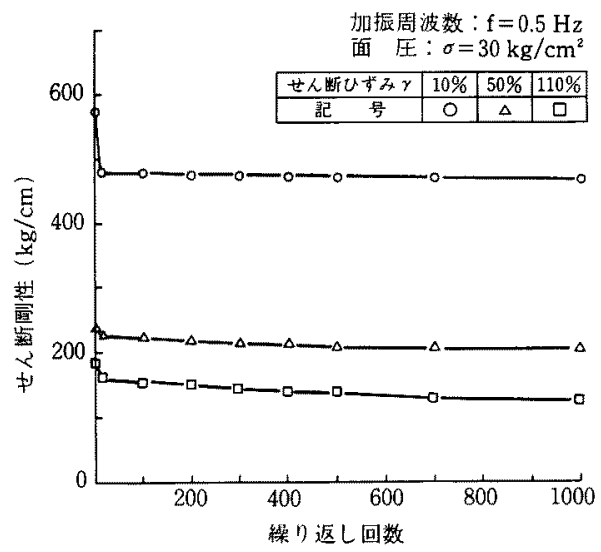

図24 せん断用性の連続くり返し数依存性

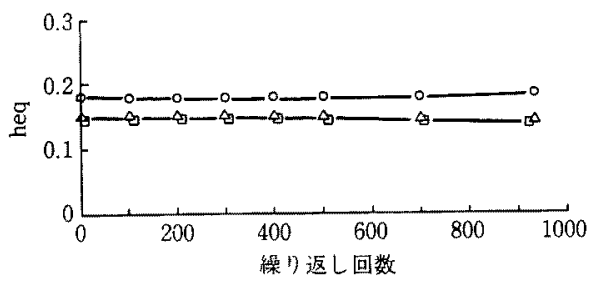

図25等価粘性減衰定数の連続くり返し数依存性 (記号は图24と同じ)

\section{4 振動数依存性}

高減衰免震 ゴムの性能の振動数依存性を図27， 図28に示す。図27を見ると振動数が高くなるにつ 九若干用性が增加しているが，その温度依存性が かなり小さい(後述)ことを考えると剛性の振動数 依存性は考えなくてもよい、また 振動数依存性を示さない。

\section{5 温度依存性}

免震ゴムに求められる重要項目の一つとして岡 性及び減衰性能の温度依存性の小さいことがあげ

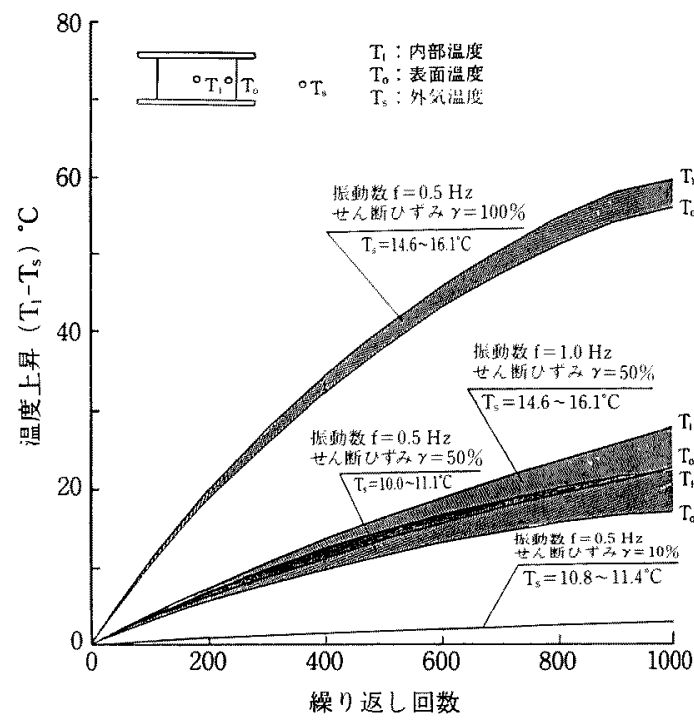

図26連続くり返し変形による高隇衰免震ゴムの温 度上䍙

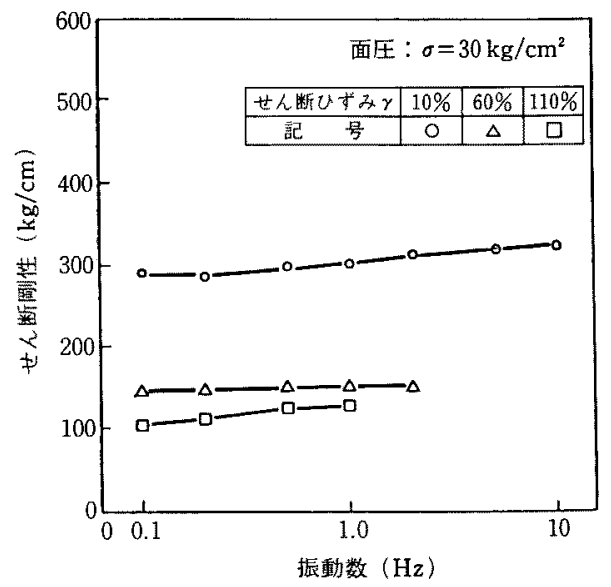

図27 世ん断㓮性の振動数依存性 


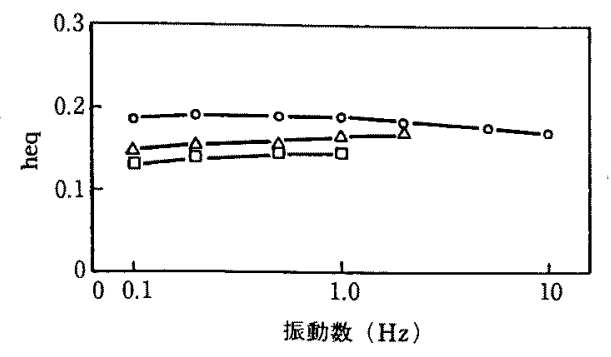

図28 等価粘珄隇衰定数の振動数依存性(記号は図 27 と同じ)

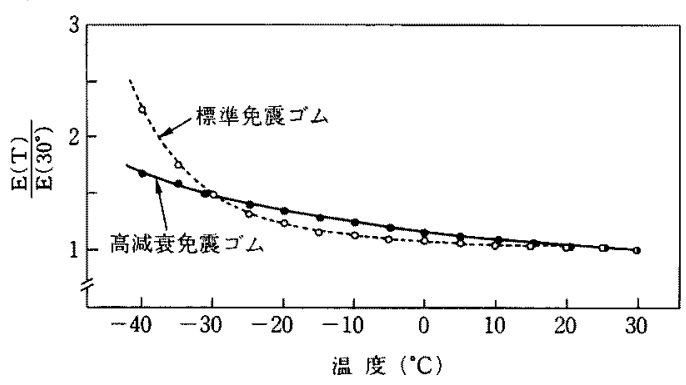

図29高減衰免震ゴムに拈ける用性の温度依存性.

各温度における用性を $30^{\circ} \mathrm{C}$ 剛性で規格化 してある。

られる。なぜなら免震ゴムの使用される温度範囲 はかなり広く3)，これらの特性の変化が直接形状 設計を左右するからである。図29は高減衰免震ゴ ムの剛性の温度依存性を示している。ここでは, 各温度に打ける剛性 $(E(\mathrm{~T}))$ を $30^{\circ} \mathrm{C}$ に扣ける佣性 $\left(E\left(30^{\circ}\right)\right)$ で規格化した值として表示されている。 免震ゴムの使用温度 $\left(-30^{\circ} \mathrm{C} \sim 30^{\circ} \mathrm{C}\right)$ を考えた場 合, 高减衰免震ゴムは標潐的天然ゴム系免震ゴム (低ヒステリシス性)と比べてほとんと遜色のない ものとなっている.

\section{4. 高減衰免震ゴムのクリープ特性}

免震ゴムは極めて長期間建物を支えるため圧縮 クリープを小さくすることが求められる．免震ゴ ムの王縮クリープは一般的には建物の沈下，特に 不等沈下をもたらすといらことで警戒されるが， 実際に拉こる免震ゴムの圧縮クリープ量は通常の 地盤沈下のレベルに比べるとかなり小さい．しか しここで重要なことは例之数\%の圧縮変形であっ ても免震ゴム内に大きな局部ひずみ(引張りひず み)を生じるといら点にある5).

免震ゴムに荷重を載せたときの沈下量 $(\varepsilon)$ は初

(49)

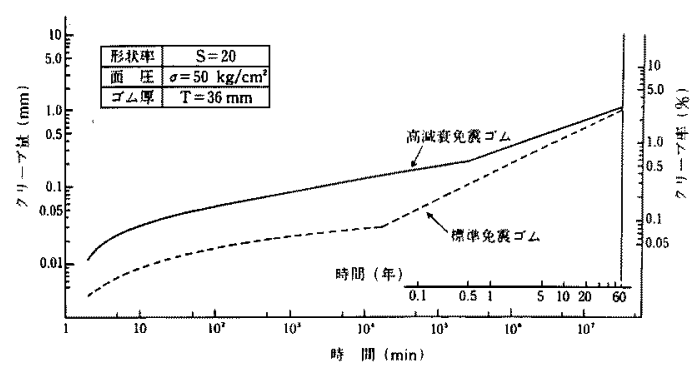

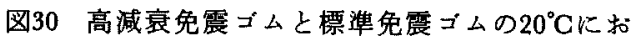
けるクリープ曲線 (両対数表示).

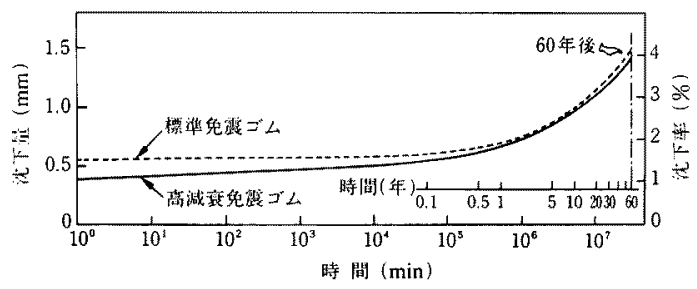

図31 図30クリープ量に初期沈下量 $\left(\varepsilon_{0}\right)$ を加えた全 沈下量 $(\varepsilon)$ 曲線 (片対数表示).

期沈下量 $\left(\varepsilon_{0}\right)$ とその後時間とともに增加する沈下 量 $(\Delta \varepsilon=$ タリープ)の和で与兄られるが, 積層ゴ ムの圧縮クリープの特敳としてクリープ量と時間 を両対数表示すると特異な曲線形状(初期にはゆ るやかな曲線となるが一定時間後には直線とな る)を示す3).したがって直線部の外挿より長期 クリープ量を推定することが可能である．図30は 標準的天然ゴム系免震ゴムと比較したときの高減 衰免震ゴムのクリープ曲線である。初期時間域で は高減京免震ゴムのクリープが標準免震ゴムより 若干大きいが，定常の直線域に入るとむしろ高減 衰免震ゴムの勾配が標準免震ゴムのそれより小さ くなる。この結果として例えば60年後には両者は ほほ同じ大きさのクリープ量となっている。そこ でこのクリープ $(\Delta \varepsilon)$ と $\varepsilon_{0}$ を加えた全沈下量 $(\varepsilon)$ の 時間変化を示したものが図31であり, 両者が同等 の沈下量になることがわかる。このように高隇衰 免震ゴムはその高減衰性にもかかからず標準免震 ゴムと同等の低クリープ性を示す。

\section{5. 高減衰免震ゴムの微小変形特性}

$3.1 て ゙$ 述べたよらに，高減衰免震ゴムは典型的 な力学非線形材料であり特に小变形領域ではその 傾向が強い，そこで非常に小さい变形(せん断ひ 
ずみが0.1〜10\%)下で高減衰免震ゴムがどのよう に挙動するが早について述べることにする。

図32，図33はおのおのせん断ひずみが0.1〜 1.0\%，1〜10\%に和けるとステリシスルーブであ る.本質的には図15，図16と同じである，そこで これらのひずみ域での凨性と等価粘性減衰定数を せん断ひずみに対してプロットしたのが図34，図 35である，剛性はひずみが低下するにつれて増加 するが，せん断ひずみが約 $1 \%$ になると最大にな り，そのときの剛性は $100 \%$ ひずみ時の剛性の約 4 倍の大きさとなっている.

一方 $h_{\mathrm{eq}}$ はせん断ひずみが数\%以上では 0.15 以 上ひずみが $1 \%$ の時でも0.12を保っている。こ の点が，低ひずみ域では弾性のみで减衰効果を発 現しない弾塑性ダンパーとは大きく異なるところ である。ただしひずみが $1 \%$ 以下になると高減衰 免震ゴムも $h_{\mathrm{eq}}$ がかなり低下する.

高減衰兔震ゴムが低ひずみ域でこのよらに挙動 することは強風などから建物の摇れを守るのに好

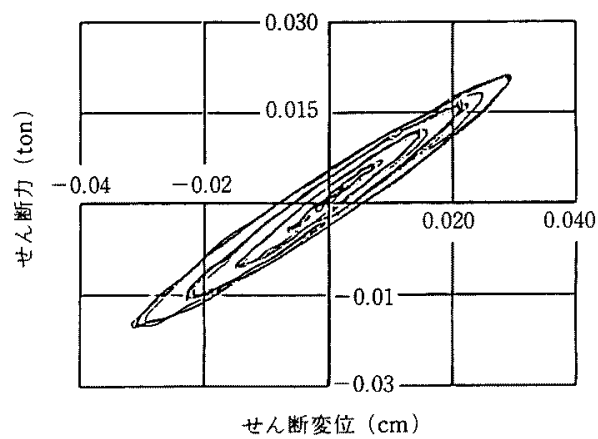

図32钽小せん断ひずみ $(0.1 \%$ 1.0\%) 下での高減 衰免震ゴムのヒステリシスループ

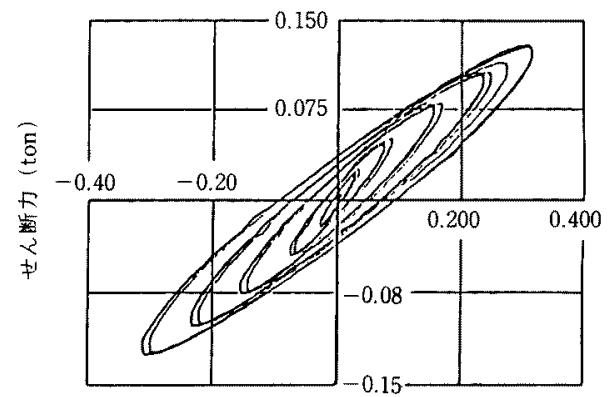

せん断変位 $(\mathrm{cm})$

図33図32と同種プロット，ただしせん断ひずみが $1 \sim 10 \%$
適である，風による入力ェネルギーは地震時のそ れに比べるとはるかに小さいが，それです標準免 震ゴムのみの上に建物を載せた状態では建物が風 で摇れるため住人の船醉い現象が起こる，高減衰 免震ゴムは小变形での剛性が高くかつかなり大き い減衰性能を持っているため風摇九防止のトリガ 一が不要である.

しかし一方, 微小変形時の剛性の増加は免震ゴ ムに免震機能と棈振動(例えば交通振動，精密機 器に対する地盤振動)防止を兼備させるのに望ま しいことではない。この点に関し高減哀免震ゴム の場合現在までのところ 2 種類の異なった報告が なされている。一つは大林組の報告であり，トラ ック振動では $31.5 \mathrm{~Hz}$ と $63 \mathrm{~Hz}$ を含む $18 \mathrm{~Hz}$ 程度 以上の振動数範囲で防振効果のあることが実験的 に確められている7（図36）。また，63 Hzを重要 視する地下鉄の構造物に対しては顕著な防振効果 のあることが計算で求められている(図37).

一方鹿島建設の計算では防振効果があまり期待

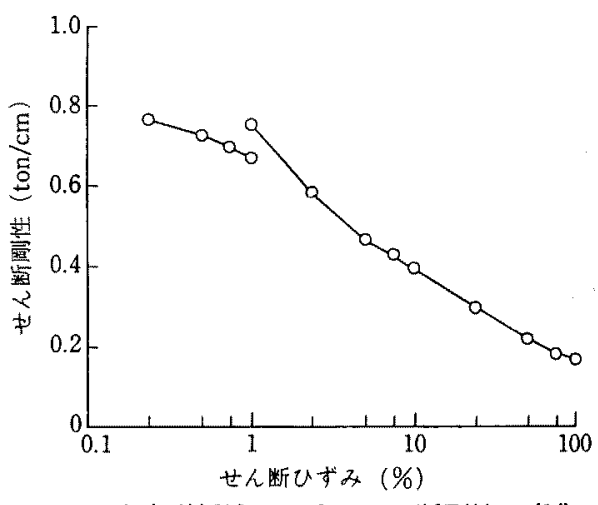

図34 小变形領域におけるせん断剛性の変化

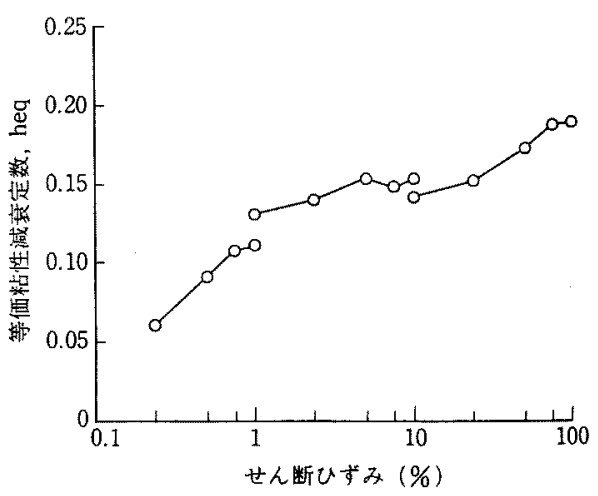

図35 小変形領域に拈ける等価粘珄減哀定数の変化 

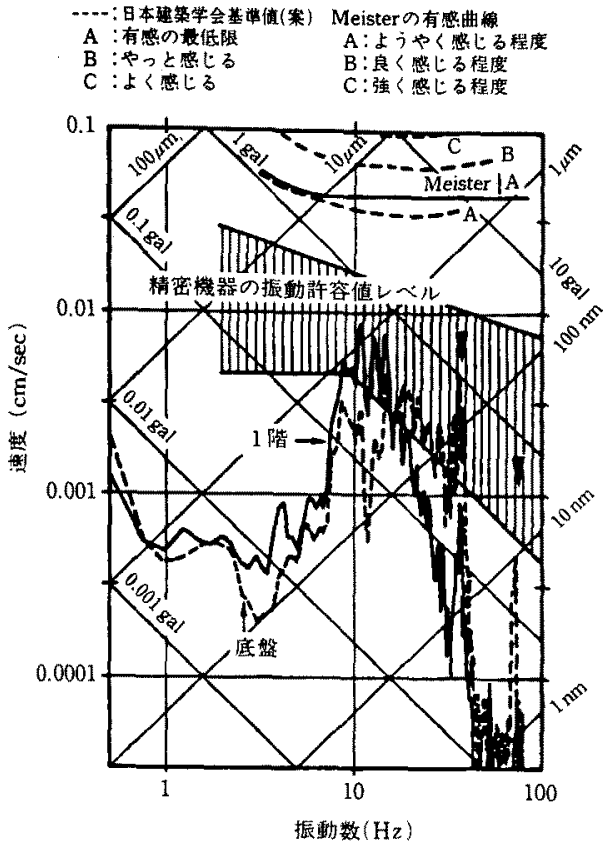

図36トラック走行 $(30 \mathrm{~km} / \mathrm{hr})$ 時の上下方向の振 動，高減衰免震ゴムを使用した建物 (1階)と 地盤の差

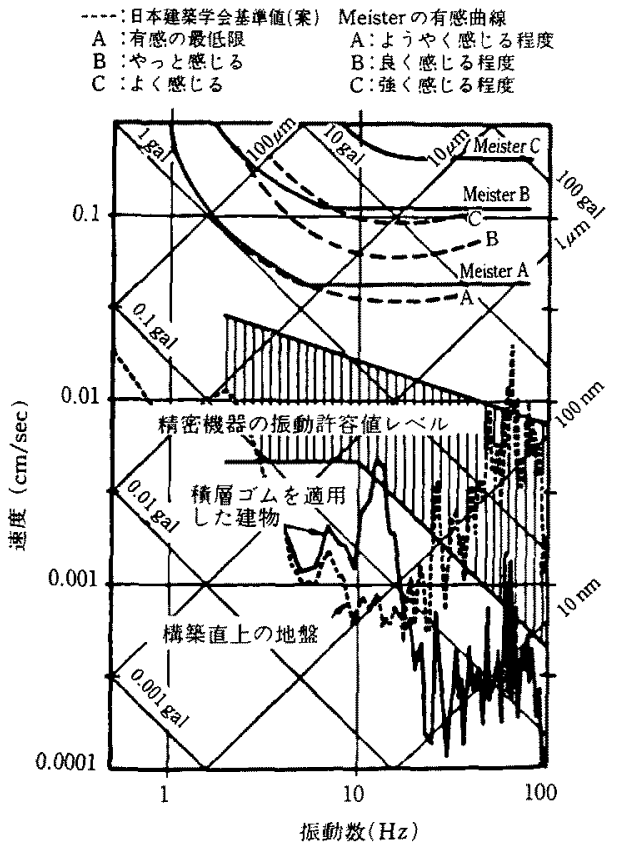

図37地下鉄構築直上建物に高減衰免震 ゴム適用 したよきの上下方向の振動(計算例)

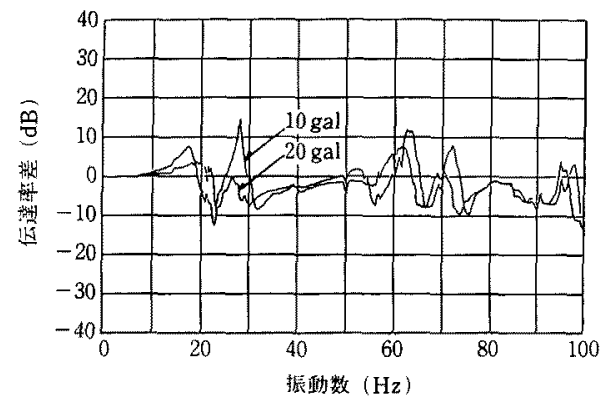

図38振動台上の模型建物に高減衰兔震ゴムを用い ない場合と用いた場合の振動层達率の差( イナスの值が防振効果の大きさを示す)

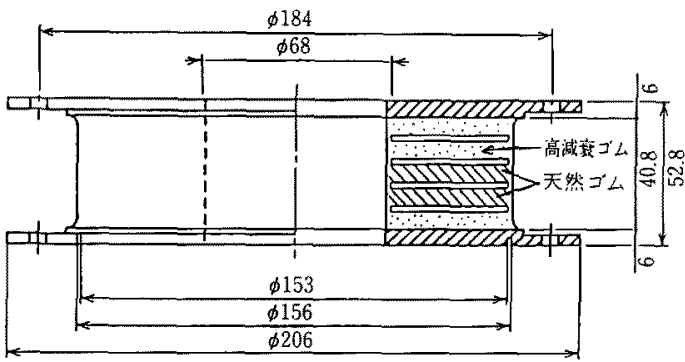

図39複合型免震ゴム

できないだろらという結果になっている゙(図 38).このため鹿島建設とブリヂストンは高減衰 ゴムと一般の低補強天然ゴム(標準免震ゴム用) と を図39のよらに複合化した免震ゴムを考案し た6).この場合複合免震ゴムは微小变形時には低 補強天然ゴムの特性を示すが大形変になるにつれ 高減衰ゴムの特性を示すよらになる。すなわら微 小变形時の剛性の増加が非常に小さいことを実験 的に確かめている(図40(a)，(b)，(c))，いずれにし 万高減餥免震ゴムがどの程度の微振動防止効果を 示すかは今後の評価を待たねばならない，

\section{6. 地震に対する高減衰免震ゴムの効果}

6.1 大地震に対する効果(シミュレーション)

これまで述べてきたよらに，高減衰免震ゴムは 等価粘性减衰定数が0.15以上であるため大地震に 対しては優れた免震效果を発揮するであるらこと は容易に予測されることである．東急建設の研究 陣は高減㚃免震ゴムを用いた免震建物に，表 1 で 与えられる各種地震波を入力したときの建物の応 答をシミュレートした、ただし等価粘性減衰定数 
(a)

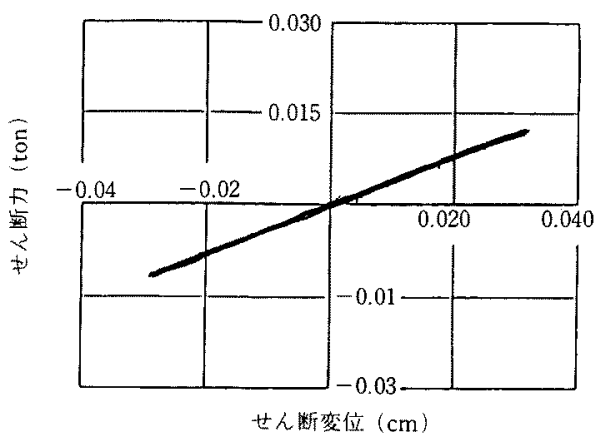

(b)

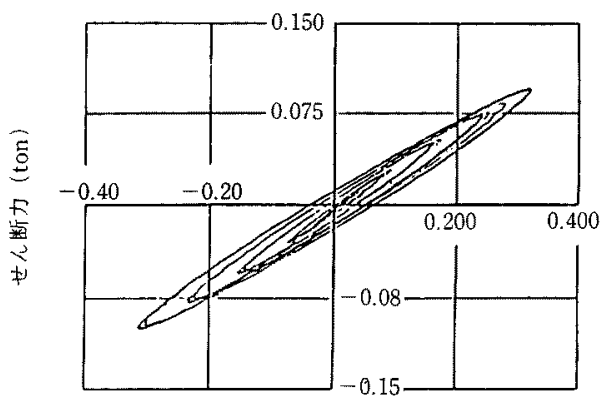

せん断変位 $(\mathrm{cm})$

(c)

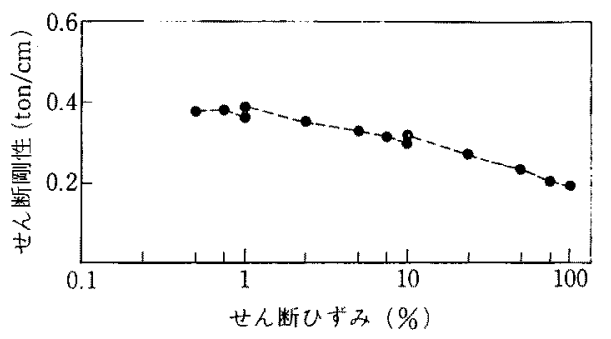

図40 小変形領域に叔ける複合型免震ゴムのヒステ リシス特性：(a)せん断ひずみ $0.1 \sim 1.0 \% ，$ (b) せん断ひず仗 1 10\%，(c)せん断用性のひず 难存性

は0.12を用いている8)。図41，図42は得られた加 速度応答スペクトル及び変位応答スペクトルであ る. 図41で示される最大加速度はいずれい地震波 に対しても表 1 で与方られる力の最大加速度の 1/5程度となっている，またそのときの建物の最 大の変位量ははぼ設計許容変位 $(30 \mathrm{~cm})$ 内に収。 ている(図42).これらの結果は大地震に対する高 減衰免震ゴムの免震効果を裏づけるものである。
表 1 各種地震波とその最大加速度

\begin{tabular}{c|c}
\hline 地 震 波 名 & $\begin{array}{c}\text { 最大加速度 } \\
\text { [gal] }\end{array}$ \\
\hline EL-CENTRO, NS & 511 \\
\hline TAFT, EW & 497 \\
\hline HACHINOHE, NS & 330 \\
\hline TH 030-1FL, NS & 367 \\
\hline 人工地震波 & 137 \\
\hline
\end{tabular}

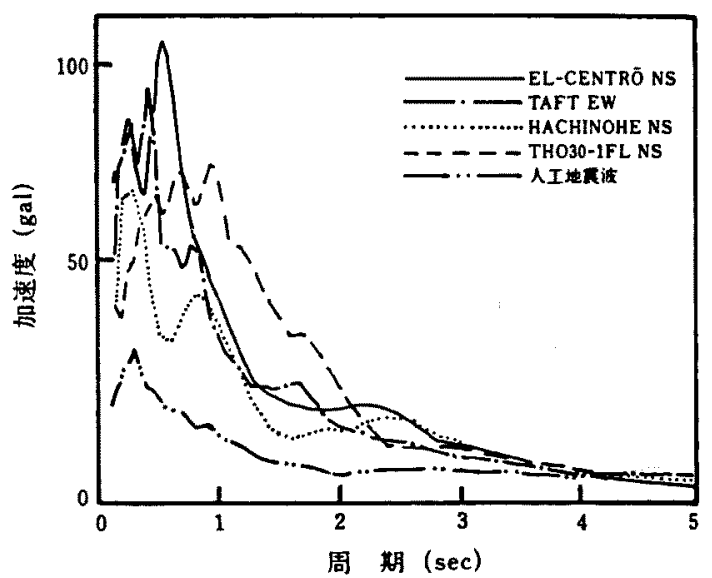

园41高減衰免震ゴムを用いた建物に表 1 の各種地 震波を入力したときの加速度応答スペクトル

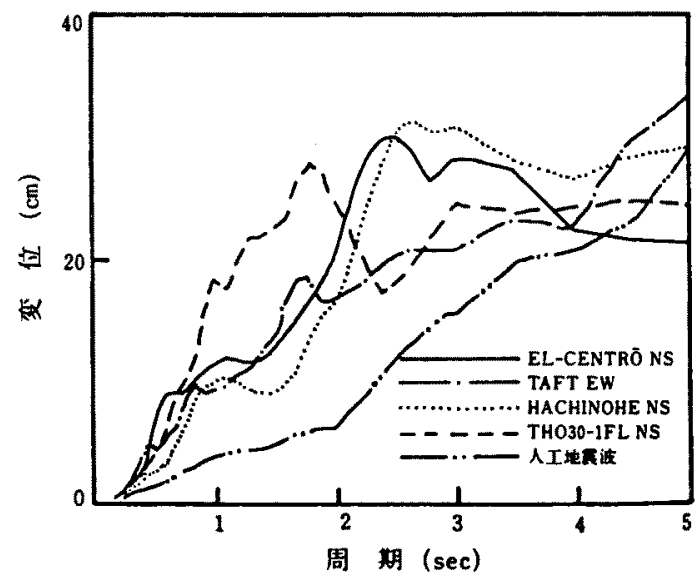

図42図41に関する变位応答スペクトル

\section{2 小地㶾に対する効果(実際の観測結果)}

すべての免震構造は大地震に対しては優れた免 震効果を発揮するよらに設計されている。しかし 中，小地震に対してる効果を発揮するかどらかは 
使用するダンパーに依存しており，一般に弾塑性 ダンパーは兔震効果を発揮しにくく(前述), 粘性 ダンパーやオイルダンパーは免震効果を発揮しや すい，さて高減衰免震ゴムの場合について貴重な 観測結果が大林組から報告されている.

大林組の清瀬市 (東京)にある実験棟は高減衰免 震ゴムを用いた兔震建物となって拈り，1987年 6 月の茨城紧南西部を震源とする地震 (東京震度 3) での観測結果が得られている7 (図43)。この図は 地表面及び免震建物の 1 階床上で観測された東西 及び南北方向の加速度の時間変化である，地表面 での最大加速度が13 gal であったのに対し兔震建 物上では最大加速度が 3〜 4 gal に減少しており， 免震構造とすることにより地震のェネルギーが1/ 3〜1/4に低減されることがわかる。

一般に震度 4 の中地震では地表面の最大加速度 は50〜100 gal 程度となるが，この観測例の13 $\mathrm{gal}$ の小地震に対し優れた免震効果があったといらこ とは高減衰免震ゴムが小さな地震に対してるかな りの免震効果を発揮するであるらと期待させる。

\section{7. 高滅衰免震ゴムにおけるダンピング発現の メカニズム}

日頃，あまりゴム材料と関係のないユーザーに とってゴムが大きな減衰機能を持つといらことが 不思議であるらしい。これは繰り返し引張っても 忹とんど元の状態にるどる輪ゴムのイメージが強 いからであろら、しかしゴム屋の立場からみる と，逆にすべてのゴム材料は大なり小なり減衰機
能(ヒステりシス効果)を持っているといらことが 常識的である，そこで基礎的なことではあるが， 今一度ゴム材料にお河る減衰機能発現のメカ二ズ ムについて少し考えてみることにしたい。

\section{1 理想ゴム弾性体}

周知のとおりゴム弾性論によると，ゴム分子鎖 は末変形の上きェントロピー最大(エネルギー最 小)の状態にありこれが引張られるとェントロ ピーが減少し系のエネルギーが増加する。したが って力を取り去ると元のェントロピー状態に戻ろ うとする。このため化学結合架橋点で固定された ゴム分子鎖は力を取り去ると元の構造，形状に戻 り，そのときの応力〜ひずみ曲線は加荷時と除荷 時が全く重なるループを描く（図44(a))，ただしこ こで注意すべきことは，このよらな理想ゴム弾性 論が成り立つのは拉の括のの分子鎖が独立に動く ことができ，かつ分子鎖同志の相互作用がない， すなわら摩擦係数がゼ口のときである。

\section{2 実在の架橋純ゴム}

しかしながら奏在のゴム架橋物の場合，分子鎖 間にはフォンデルワールスカや水素結合が動くた め分子鎖の動きによってかなりの高摩擦 (高粘着) が発生する。このため，分子鎖のからみ合いや凝 集による弱い凝似架橋点が多数に存在する奏際の 架橋ゴムに力が加えられると，力の大きさに応じ て分子鎖のすべりや凝集部分の分離などが起こ り，結果的には凝似架橋点の数が減少する。した がって除荷時は加荷時に比べ，凝似架橋点の減少 した割合に応じ応力が低下寸る。すなわち応力〜

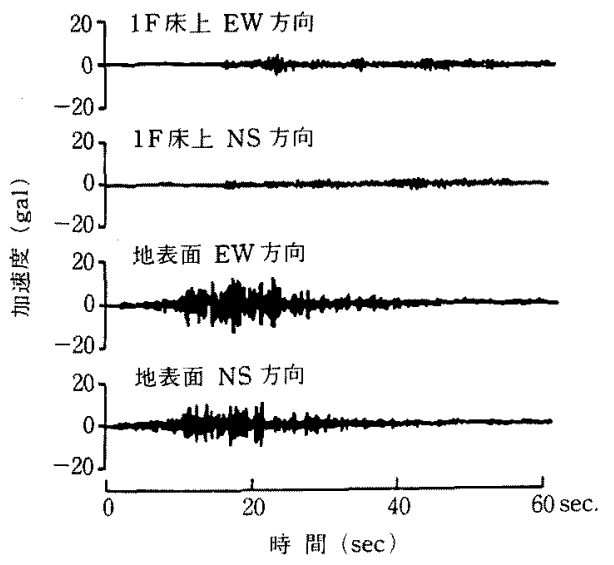

図43高減衰兔震ゴムを用いた免震建物の地震観測 実例

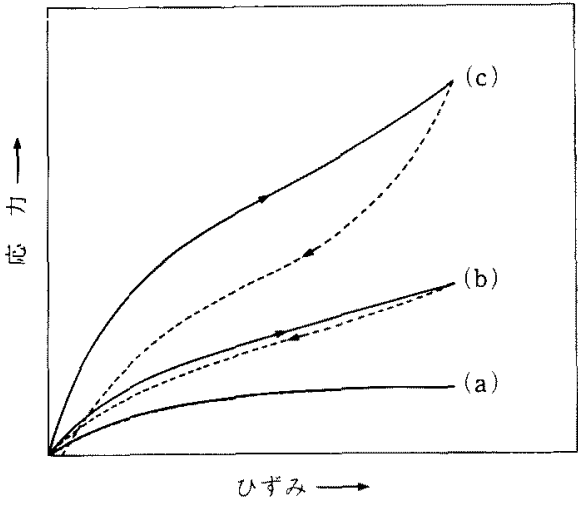

图44ゴムの応力〜ひすず曲線：(a)理想ゴ弾性 体，(b)実在の架橋ゴム，(c)カーボン充てん ゴム 
ひずみ曲線がヒステリシスループを描く(図44 (b)).このヒステリシスループで囲まれたェネル ギー(ヒステリシスエネルギー)が，ゴムの变形時 に発生する分子摩擦エネルギーであり熱エネルギ 一として采外に放出される，標準免震ゴムに見ら れる若干のヒステリシスェネルギーは主にこのよ らなメカニズムで発現したものと考えてょい．

\section{3 高減衰免㶾ゴム}

ゴムにカーボンなどの充てん戍を加えると，上 記のゴム分子鎖自体の摩擦に加えカーボン表面へ のゴムの吸着やカーボン同志の連続相，不連続相 の形成によって，みかけの粘性俰数 $[\eta]$ が飛嚁 的に増加する(式(3)) 9).

$$
\eta=\eta_{0}=\left(1+2.5 \phi+14.1 \phi^{2}\right)
$$

ここで和はカーボンを含まないときのみかけの 粘性係数，中はカーボンの含有分率である。すな わちこのよらな系に力を加兄ると，前述の分子鎖 のすべりはもとよりゴム分子鎖のカーボン表面か らの脱着 $\rightarrow$ 再吸着, カーボン凝集相の破罗と再凝 集などが起こり多大の摩擦エネルギーが発生す る.これを応力〜ひずみ曲線でみると除荷時の応 力の低下が大きく，ヒステリシスェネルギーの大 きいループとなる(図44(c)).

高減衰免震ゴムには，减衰能力を極めて大きく しかつクリープや性能の温度依存性を小さくする ために特殊な充てん剂が配合されている、したが ってゴムと特殊充てん视によって形成された系内 で起こる内部摩擦によって, 系に加えられた力学 的エネルギーの一部を熱エネルギーに变换して消 費させる働きが高減衰免震ゴムのダンピング発現 のメカニズムである.

\section{8. あとがき}

高隇衰免震ゴムはコストダウン効果，施行，メ インテナンスの容易さ及び中小地震に対する期待 などがあるため, 現在かなり多数のゼネコンが高 减衰免震ゴムを用いた免震建物を建築せンターで 評定中である。

一方高減衰免震ゴムの適用法の一つとして部分 免震システムがある．これは新築ではなく既存ビ ルの免震を行らのに, 建物全体ではなく各階, 各 床, 各機器レベルを免震させようというすのであ る(もっともフメリカでは既存ビルの免震が行な われ始めている)。このような免震の場合一般に 被免震体の重量が軽いため通常形状の免震ゴムで

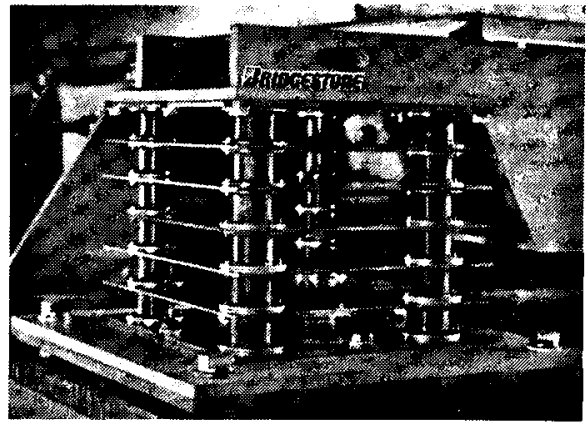

図45多段式免震ゴムシステム

は背高ノッポにならざるを得ず，この結果非常に 來屈しやすくなる。これを解消するために開発さ れたのが多段式免震ゴムシステムであり，一般に 4 個の小型免票ゴムを鉄板で連結したニニットを 数段重ね合せたものである(図45).

高减衰免震ゴムにとって今後の課題は，その複 雑なばね特性, 減衰特性を建物の地震解析之連結 するためのソフトの開発であり，現在理論的，実 験的に検討されている．いずれにしろ高减衰免震 ゴムにしてもその他の免震構造体にしてるまだ串 際の地震経験が少なく，その免震効果を正確に評 価するには今後の数多くの観測結果を待つ以外に ない。

\section{参考 文 献}

1）讀売新聞：12月18日，1987，データは竹中工務店 より入手

2）武田寿一：構造物の免震，防振，制振，技報堂 (1988), p. 140

3）深堸美英：日ゴム協誌，60,397，1987

4) Kelly, J. M., Tasi, H. C.: Structural Engineering and Structural Mechanics, Report No. UCB/SESM-84/17, 1984

5) Seki, W., Fukahori, Y., Iseda, Y., \& Matsunaga, T.: Rub. Chem. Tech., 60, 856, 1987

6）八坂厚彦，飯塚真巨，深堀美英，芳沢利和：昭和 63 年度日本建筑学会大会(関東), 講演 No, 2197 (1988)

7）武田寿一，岡田 宏, 内田 幄ら：大林組技術研 究所報 No. 36, 103, 1988

8）小嶋英治，林田敏弘，川久保政茂ら：東急建設技 術研究所報 No. 14, 135, 1988

9) Kraus, G.: Rub. Chem. Tech., 38, 1070(1965) 